\title{
Redescription of Tenuipalpus palosapis Corpuz- Raros (Trombidiformes: Tenuipalpidae) from the Philippines, with comparison to related species
}

\author{
Elizeu B. Castro, Jennifer J. Beard, Ronald Ochoa \& Reinaldo J. F. Feres
}

To cite this article: Elizeu B. Castro, Jennifer J. Beard, Ronald Ochoa \& Reinaldo J. F. Feres (2018) Redescription of Tenuipalpus palosapis Corpuz-Raros (Trombidiformes: Tenuipalpidae) from the Philippines, with comparison to related species, International Journal of Acarology, 44:2-3, 80-89, DOI: $10.1080 / 01647954.2018 .1453543$

To link to this article: https://doi.org/10.1080/01647954.2018.1453543

\section{曲 Published online: 22 Mar 2018.}

\section{Submit your article to this journal $\llbracket$}

Џ Article views: 37

View Crossmark data ¿

Citing articles: 1 View citing articles $₫$ 


\title{
Redescription of Tenuipalpus palosapis Corpuz-Raros (Trombidiformes: Tenuipalpidae) from the Philippines, with comparison to related species
}

\author{
Elizeu B. Castro ${ }^{\mathrm{a}, \mathrm{b}}$, Jennifer J. Beard ${ }^{c}$, Ronald Ochoa ${ }^{\mathrm{d}}$ and Reinaldo J. F. Feres ${ }^{\mathrm{a}, \mathrm{e}}$
}

aDepartment of Zoology and Botany, Institute of Biosciences, Humanities and Exact Sciences (Ibilce), São Paulo State University (UNESP), São José do Rio Preto, Brazil; ' US National Insect and Mite Collection, Department of Entomology, Smithsonian Museum of Natural History, Washington DC, USA; 'Biodiversity and Geosciences, Queensland Museum, South Brisbane, Australia; dSystematic Entomology Laboratory (SEL), Agricultural Research Service (ARS), United States Department of Agriculture (USDA), Beltsville Agricultural Research Centre (BARC), Beltsville, MD, USA; ${ }^{\circ} C N P q-$ Brazil researcher

\begin{abstract}
Tenuipalpus palosapis Corpuz-Raros, 1978 was described based on specimens collected on Anisoptera thurifera Blume and Shorea squamata Benth. and Hook.f. (both Dipterocarpaceae), from Laguna, Republic of the Philippines. In this article, we redescribe T. palosapis based on paratype specimens deposited at the National Insect and Mite Collection, National Museum of Natural History, Smithsonian Institution (NMNH), located at Beltsville, Maryland, USA. We compare T. palosapis with three other morphologically similar species of Tenuipalpus from the Asia-Pacific region, Tenuipalpus antipodus Collyer (New Zealand), Tenuipalpus guamensis Baker (Guam), and Tenuipalpus orilloi Rimando (Republic of the Philippines), and we demonstrate that the females of these species share a welldeveloped and similarly shaped, genitoventral plate. Based on literature, the latter three species have been recorded on a broader range of host plants than has been recorded for many other species of Tenuipalpus, and have been intercepted at ports of entry in the United States and New Zealand. A key to these four species is provided.
\end{abstract}

\section{ARTICLE HISTORY}

Received 7 December 2017 Accepted 13 March 2018

Published online 23 March 2018

\section{KEYWORDS}

Taxonomy; flat mites; false spider mites; genitoventral plate; Tenuipalpus antipodus; Tenuipalpus guamensis Tenuipalpus orilloi:

Caribbean; Indonesia; Asia; biogeography

\section{Introduction}

The flat mites (Acari: Tenuipalpidae) comprise over 1200 described species in 40 genera (Mesa et al. 2009; Beard et al. 2014, 2016; Castro et al. 2015). Tenuipalpus Donnadieu is the largest genus of this family with more than 300 species described (Mesa et al. 2009; Castro et al. 2016a, 2017; Welbourn et al. 2017). Recently, after resurrecting Colopalpus (Castro et al. 2015), Castro et al. (2016b) proposed the division of Tenuipalpus in two groups: sensu stricto, a homogenous group with body projections associated with opisthosomal setae $c 3$; and sensu lato, a heterogenous group without the body projections associated with setae $c 3$.

T. palosapis Corpuz-Raros, 1978, a species of the sensu lato group, was described from specimens collected on the native tree species Anisoptera thurifera Blume and Shorea squamata Benth. and Hook.f. (Dipterocarpaceae), from Laguna, Republic of the Philippines. We compared T. palosapis with three other species of the sensu lato group from the Asia-Pacific region, $T$. antipodus Collyer, 1964; from New Zealand, T. guamensis Baker, 1945; from Guam and T. orilloi Rimando, 1962; from the Philippines. We demonstrate that these four species share a well-developed, and similarly shaped, genitoventral plate. Based on previous descriptions (Meyer 1979, 1993; Baker and Tuttle 1987), many Tenuipalpus species do not have a well-developed or strongly delimited genitoventral plate. Furthermore, the three species $T$. antipodus, T. guamensis and T. orilloi all occur on a wide range of host plants and have a broad distribution, including New Zealand, Taiwan, Guam, the Cook Islands, the Philippines, Indonesia, Guiana, Trinidad and China. These species have also been intercepted at ports of entry in the United States and New Zealand (Baker 1945; Collyer 1973; Corpuz-Raros 1989; Xu and Fan 2010).

Herein, we redescribe the female and male of $T$. palosapis, presenting the description in a standardized format, and we discuss character states shared by these four species of the sensu lato group. The shared character states combined with a shared distribution (Asia-Pacific region) seem to indicate a possible biogeographic pattern.

\section{Material and methods}

All measurements are given in micrometers $(\mu \mathrm{m})$. The terminology used follows that of Lindquist (1985) and Mesa et al. (2009). Leg chaetotaxy is adapted from Lindquist (1985), Zhang and Fan (2004), Xu and Fan (2010), and Seeman and Beard (2011). Tarsal setae are presented as the total number of phaneres followed by the number of solenidia in parentheses. The types and paratypes of the species mentioned in this study are deposited in the National Insect and Mite Collection, National Museum of Natural History (NMNH), Smithsonian Institution, located at the Systematic Entomology Laboratory (SEL), USDA, Beltsville, Maryland, USA.

\section{Family Tenuipalpidae Berlese, 1913 \\ Genus Tenuipalpus Donnadieu, 1876}

Type species: Tenuipalpus palmatus Donnadieu, 1876 (= T. caudatus (Dugès, 1834))

\section{Diagnosis \\ (Following Castro et al. 2016a)}

Female. Body shape with prodorsum wider than opisthosoma or elongate-ovate; prodorsum with three pairs of setae $(v 2, s c 1, s c 2$; except $v 2$ absent in $T$. elegans (Collyer)); dorsal opisthosoma with 8-10 pairs of setae $(c 3, d 3, e 3, f 3, h 1, h 2$ present; $c 2, d 2$, e2 absent; $c 1, d 1, e 1, f 2$ present or absent $(d 1, e 1$ rarely absent); setae $h 2$ elongate, flagellate. Palp one to three segmented. Venter with one to two pairs of setae $3 a$ ( $3 a$ always present; $3 a 2$ present or

CONTACT Elizeu B. Castro elizeu_unesp@yahoo.com.br @ Institute of Biosciences, Humanities and Exact Sciences (Ibilce), São Paulo State University (UNESP, São José do Rio Preto, Brazil

(c) 2018 Informa UK Limited, trading as Taylor \& Francis Group 
absent) and one to four pairs of setae $4 a$ ( $4 a$ always present; $4 a 2$, $4 a 3,4 a 4$ present or absent); genitoventral plate developed or not, membranous genital flap present; commonly two pairs of pseudanal setae $p s 2-3$ present (three pairs, ps 1-ps3, rarely present).

Male. Opisthosoma distinctly narrower than that of female; legs and dorsal setae usually similar to those of female; pseudanal setae ps3 modified as a variously shaped accessory genital stylet.

Tenuipalpus palosapis Corpuz-Raros, 1978: 227

(Figure 1-9, 10(a), 11(a))

Tenuipalpus palosapis Corpuz-Raros (1978): 227

\section{Diagnosis}

Female. Dorsum completely sculptured. Prodorsum: region lateral to setae $v 2-s c 1$ with pair small globose projections, and central region with three large, distinctive globose projections, with strongly colliculate cuticle flanking the posterior projections; prodorsal setae $v 2, s c 1$ and $s c 2$ strongly barbed; $v 2$ and $s c 1$ longer than sc2. Opisthosoma: central region anterior to setae e1-e1 with a large single, medial, oblate projection, larger than prodorsal projections; dorsal opisthosomal setae barbed; setae $c 1$ and $d 1$ absent; setae $d 3$ and $e 1$ thick, subequal in length, longest on dorsal opisthosoma; setae $c 3, e 3, f 2, f 3, h 1$ short, subequal in length; setae $h 2$ elongate and flagelliform. Palps one-segmented. Ventral integument completely striated; with single fused genitoventral plate, well-developed and clearly delimited; setae $1 a$

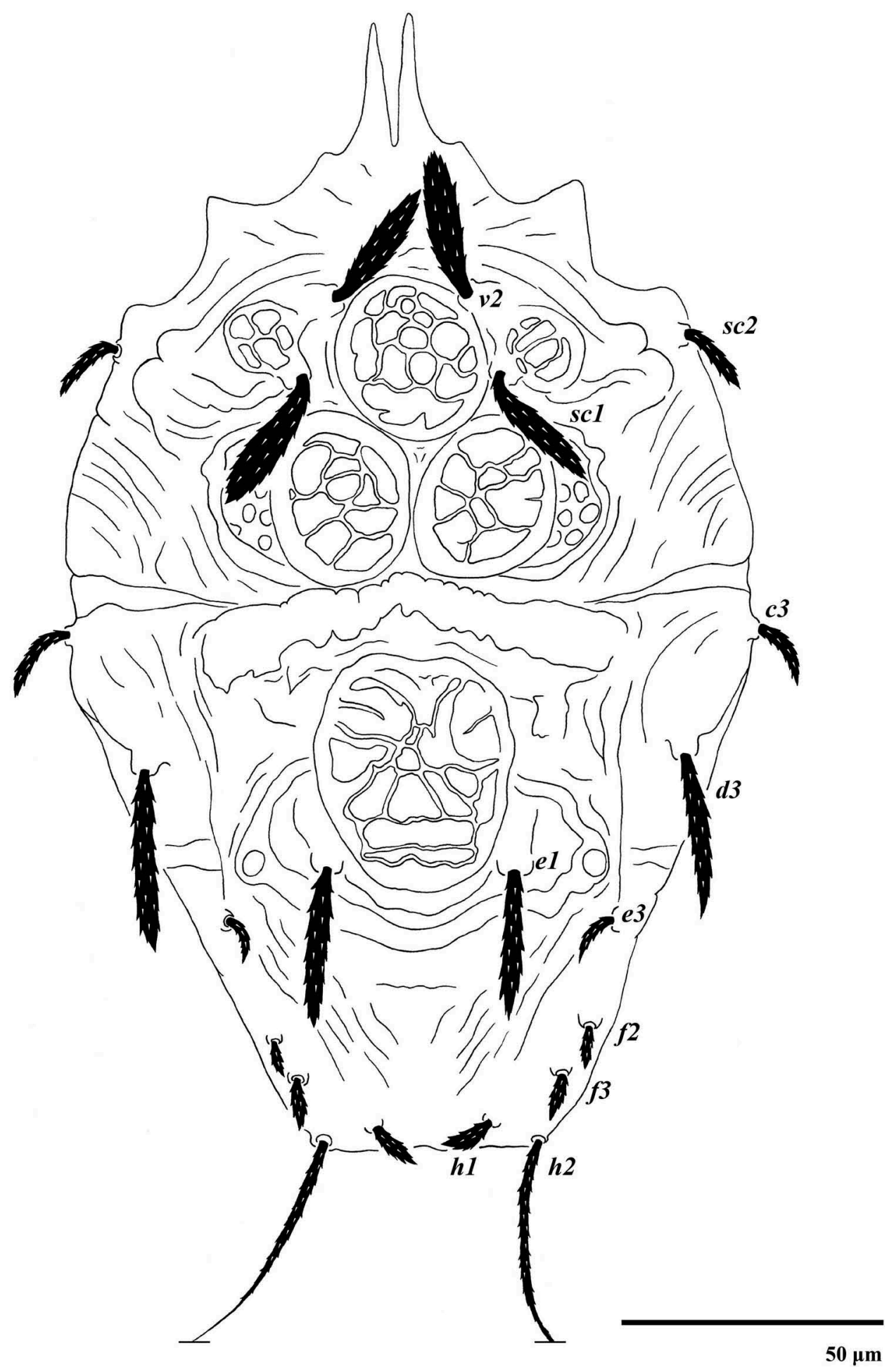

Figure 1. Tenuipalpus palosapis Corpuz-Raros (Female): dorsum. 
elongate and flagelliform; setae $4 a$ short; setae $a g, g 1-g 2$ and ps2-ps3 smooth. Legs with seta $d$ on femora and genua I-II thick, barbed and inserted in truly dorsal position.

Male. Prodorsum with projections similar to those of the female, and setae $v 2$, sc1 shorter than those of female. Opisthosomal projection smaller than prodorsal projections and weakly developed to almost absent; dorsal opisthosomal setae $c 1, d 1$ absent; setae $e 1, e 3, f 2, f 3, h 1$ short, subequal in length; setae $c 3, d 3$ thick; setae $d 3$ the longest on dorsal opisthosoma; tarsi I-II each with one additional solenidion in proximal ventrolateral position; other leg setae similar to those of the female.

\section{Material examined}

Paratypes: Three females and one male collected on A. thurifera Blume (Dipterocarpaceae), from Makiling Botanic Garden, Mount Makiling, Laguna, the Republic of the Philippines; 27 November 1976, coll. J.M. Sooto and R.C. Garcia. (USNM, DNR 331).

\section{Redescription}

Female $(n=3)$ (Figure 1-5, 10(a), 11(a)). Body measurements: distance between setae $v 2-h 1$ 147-152, sc2-sc2 100-102; other measurements: v2-v2 23-25, sc1-sc1 35-38, c3-c3 119-128, d3d3 102-104, e1-e1 31-34, e3-e3 68-71, f2-f2 57-59, f3-f3 48, h1h1 18-22, h2-h2 38-40.

Dorsum (Figure 1-2, 10(a)). Anterior margin of prodorsum with median-forked projection forming a notch, reaching middle of femur of leg I. Dorsum completely sculptured, strongly sclerotized; with pair small globose projections lateral to setae v2-sc1; central region of prodorsum with three large, distinctive globose projections; with colliculate cuticle laterally flanking the posterial projections; prodorsal setae $v 2, s c 1$ and sc2 strongly barbed; v2 and sc1 broad, lanceolate to oblanceolate, subequal in length, longer than sc2. Central region of opisthosoma with a single large, medial, oblate projection; setae $c 1, d 1$ absent; $d 3$ and $e 1$ thick, narrowly lanceolate, longest on dorsal opisthosoma; setae $c 3, e 3, f 2, f 3, h 1$ short, subequal in length; setae $h 2$ elongate and flagelliform. Setal lengths: v2 23-25, sc1 24-27, sc2 13-15, c3

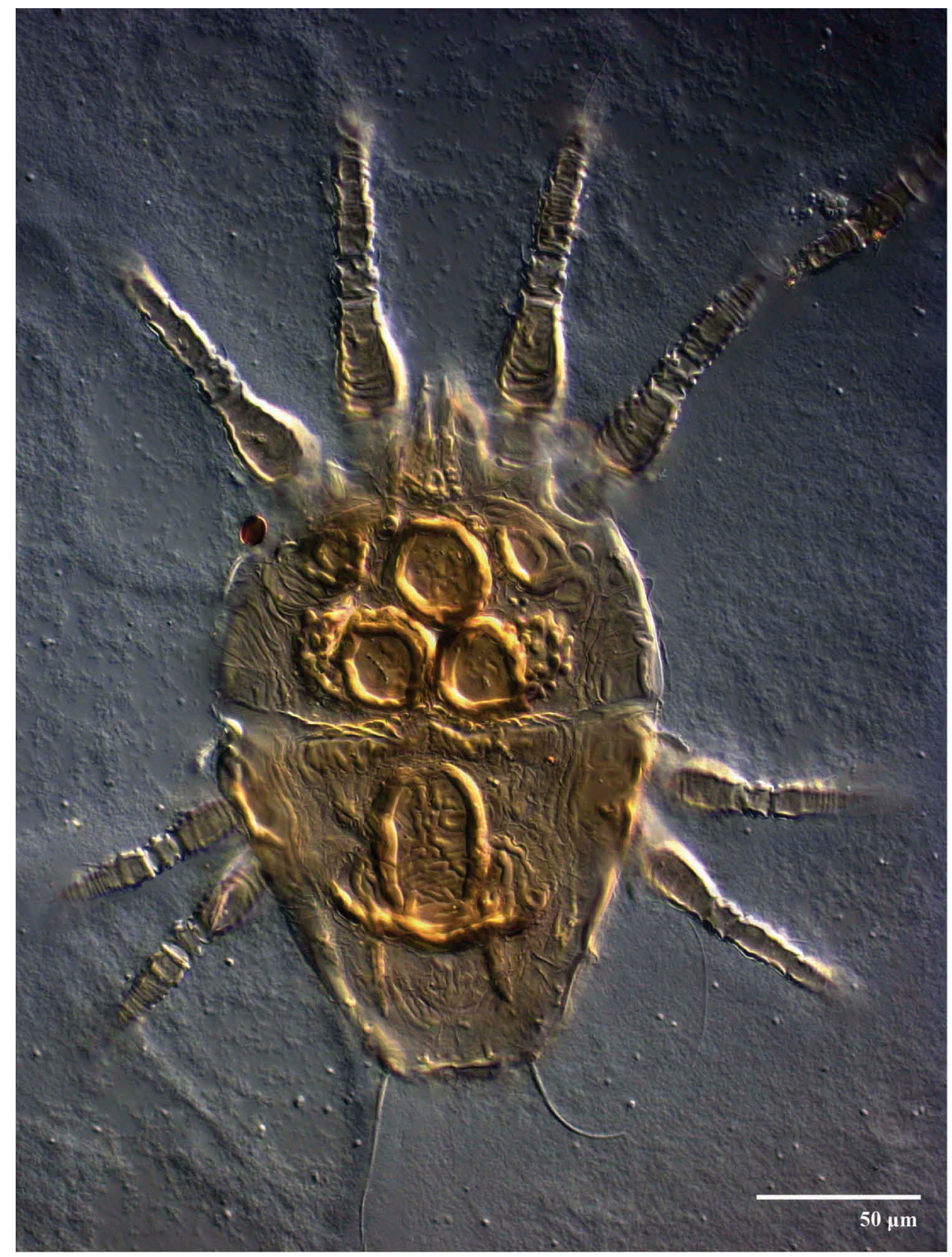

Figure 2. Differential interference contrast (DIC) image of Tenuipalpus palosapis Corpuz-Raros (Female): dorsal habitus. 


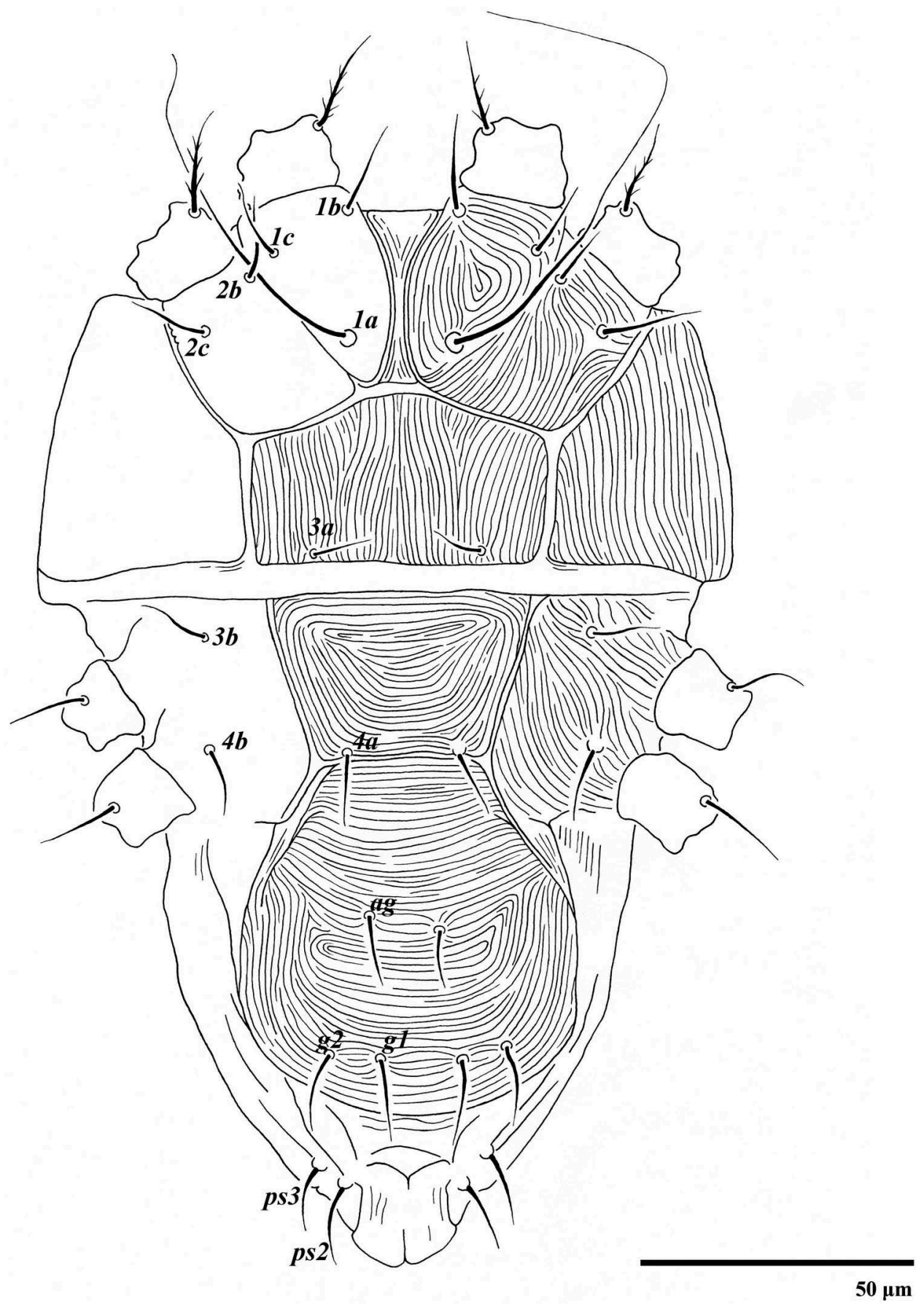

Figure 3. Tenuipalpus palosapis Corpuz-Raros (Female): venter.

12-15, d3 27-31, e1 28-29, e3 6-9, f2 6-7, f3 7-8, h1 8-9, h2 150-170.

Venter (Figure 3, 11(a)). Ventral integument completely striated; with single fused genitoventral plate, well-developed and clearly delimited; setae $1 a$ elongate and flagelliform; setae $4 a$ short; setae $a g, g 1-g 2$ and $p s 2-p s 3$ fine and smooth. Setal lengths: $1 a$ 71-74, $1 b$ 11-12, 1c 6-7, 26 9-10, 2c 11-13, 3a 6-7, 3b 9-10, 4a 9-11, 4b 8-10, ag 8-10, g1 9-10, g2 8-10, ps2 7-11, ps3 4-6.

Gnathosoma (Figure 4). Palps one-segmented, with one smooth distal seta $d$ 8-10; eupathidium and solenidion absent. Ventral setae $m$ 6-7, barbed; distance between setae $m-m$ 11-12.

Legs (Figure 5). Chaetotaxy (from coxae to tarsi): I 2-1-4-2-5-8 (1), II 2-1-4-2-5-8(1), III 1-1-2-0-3-5, IV 1-1-1-0-3-5. Seta $d$ on femora I-III short, broad, barbed; seta $d$ on genu I-II short, thick, barbed. Tarsi I-II each with one solenidion $\omega^{\prime \prime} 7-8$ and 8-9, respectively, longer than associated setae $\mathrm{ft}^{\prime \prime}$ short, lanceolate; two distal eupathidia, $p \zeta^{\prime}-p \zeta^{\prime \prime}$ (4-5 for both tarsi).

Male $(n=1)$ (Figure 6-9). Body measurements: distance between setae $v 2-h 1138, s c 2-s c 2$ 82; other measurements: v2v2 20, sc1-sc1 36, c3-c3 90, d3-d3 62, e1-e1 15, e3-e3 42, f2-f2 39, f3-f3 34, h1-h1 11, h2-h2 29.

Dorsum (Figure 6-7). Anterior margin of prodorsum with median-forked projection forming a notch, reaching middle of femur of leg I. Dorsum completely sculptured and sclerotized; central region of prodorsum with three large, distinctive globose projections. Setae v2, sc1 and sc2 broad, strongly barbed; sc1 longer than $v 2$ and $s c 2$. Opisthosoma with mostly longitudinal striation, medial globose projection weakly developed to almost absent (Figure 7); setae $c 1, d 1$ absent; setae $d 3$ subequal in length to $s c 1$, 


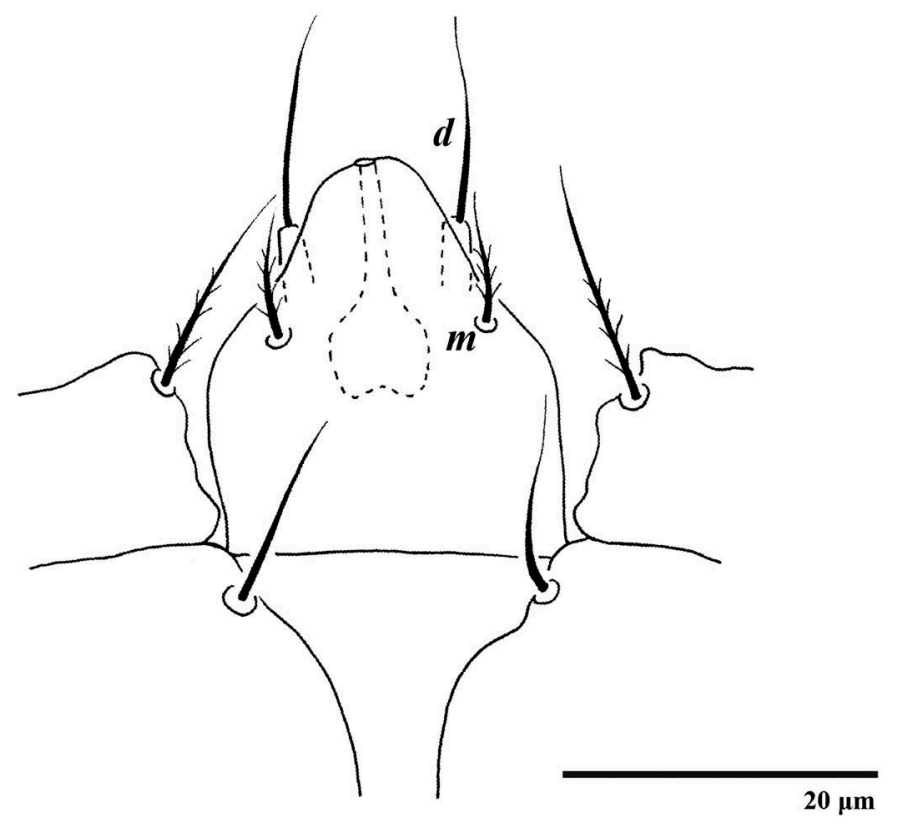

Figure 4. Tenuipalpus palosapis Corpuz-Raros (Female): ventral infracapitulum.

thick and strongly barbed; setae $e 1, e 3, f 2, f 3, h 1$ short, subequal in length, barbed. Setal lengths: $v 215, s c 120, s c 214, c 312, d 321$, e1 4, e3 9, f2 6, f3 7, h1 8, h2 150.
Venter (Figure 8(a)). Ventral integument completely striated, ventral propodosoma with mostly longitudinal striae, ventral opisthosoma with mostly transverse striae. Coxal, genital and pseudanal setae fine and smooth; setae $1 a$ elongate and flagelliform; setae $4 a$ short; setae ps 3 modified into genital accessory stylets, short thickened setae with blunt tip. Setal lengths: $1 a$ 83, $1 b 8,1 c 7,2 b 9,2 c 11,3 a 6,3 b 10,4 a 7,4 b 8, a g 7, g 19, g 2$ 10, ps2 7, ps3 7.

Aedeagus (Figure 8(b)). As figured; 70 long, finely tapered.

Gnathosoma. Palps similar to that of female, with one smooth seta $d$ 10; eupathidium and solenidion absent. Ventral setae $m 7$; distance between setae $m-m 11$.

Legs (Figure 9). Chaetotaxy (from coxae to tarsi): । 2-1-4-2-5-8 (2), II 2-1-4-2-5-8(2), III 1-1-2-0-3-5, IV 1-1-1-0-3-5. Tarsi I-II each with two solenidion, tarsi I $\omega^{\prime} 15$, $\omega^{\prime \prime}$ 9, tarsi II $\omega^{\prime} 14$, $\omega^{\prime \prime}$ 9, and two eupathidia $p \zeta^{\prime}-p \zeta^{\prime \prime}$ (all 4); solenidion $\omega^{\prime} 1$ on tarsi I-II in proximal ventrolateral position; tarsi I-II with solenidion $\omega^{\prime \prime}$ much longer than associated setae $\mathrm{ft}^{\prime \prime}$, short and lanceolate; other leg setae similar to those of the female.

\section{Discussion}

The female of T. palosapis is easily differentiated from T. antipodus, T. guamensis and T. orilloi by the completely sculptured dorsum (Figure 10) which is only weakly sculptured in the latter

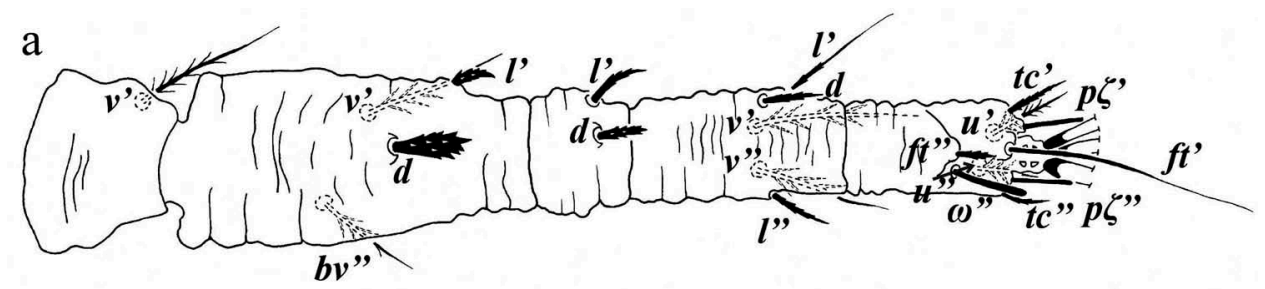

b

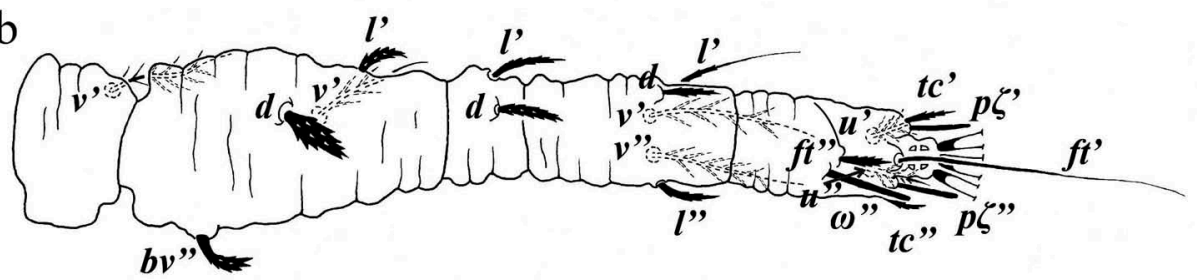

C
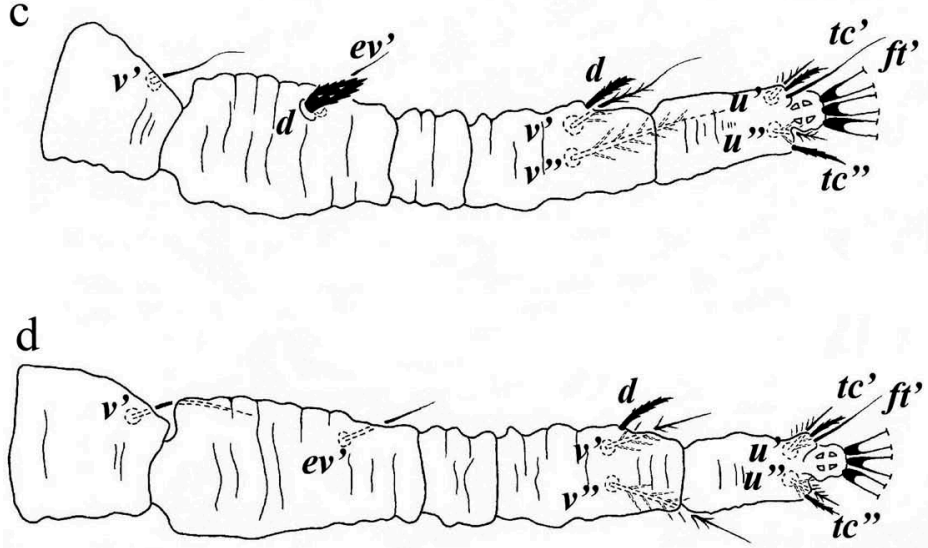


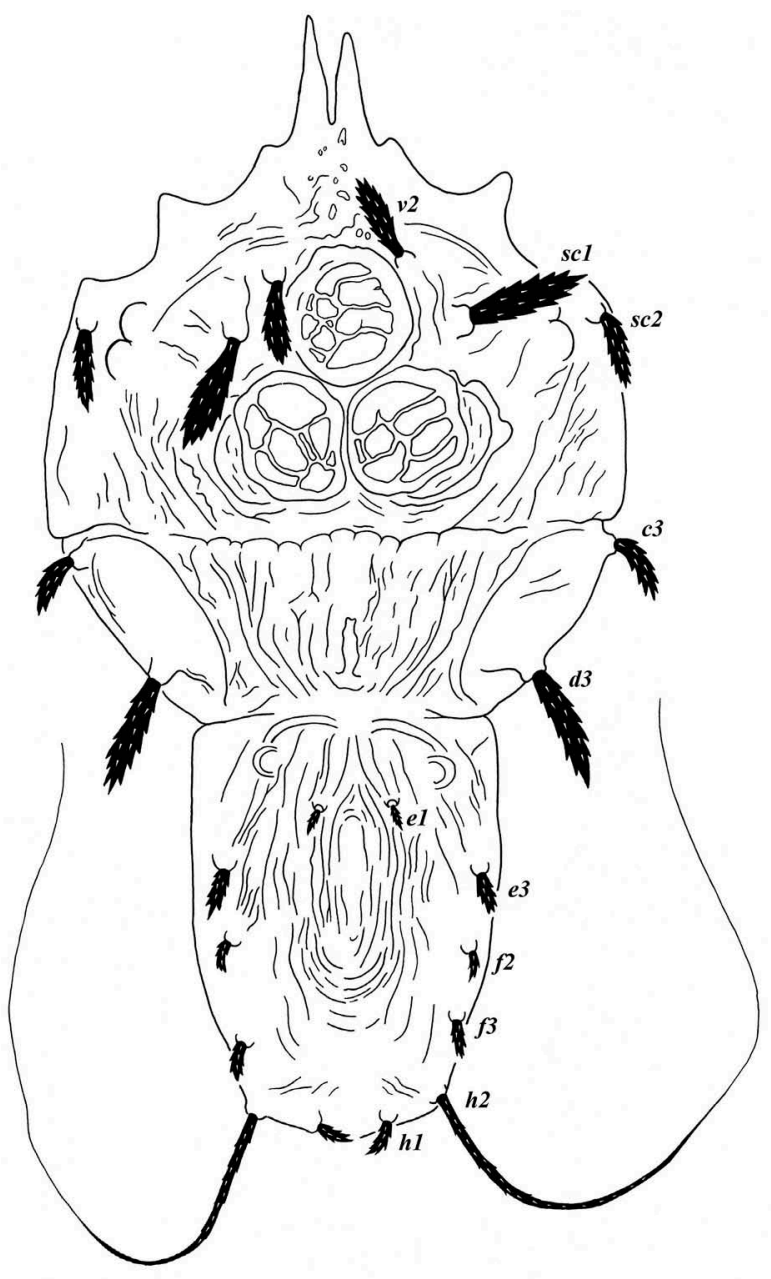

$50 \mu \mathrm{m}$

Figure 6. Tenuipalpus palosapis Corpuz-Raros (Male): dorsum.

species, and by the dorsal posterior lateral setae not being thick and long as they are in the latter species. The central region of the prodorsum of $T$. palosapis has three globose projections and the central region of the opisthosoma has a large single median oblate projection, while in the others three species, the dorsum is weakly sculptured and most posterior lateral setae are lanceolate. Despite these differences, these four species all share a single well-developed genitoventral plate, which is not present in other known Tenuipalpus species. The plate in T. palosapis is somewhat ovate being tapered anteriorly and broadly rounded posteriorly (Figure 3, 11(a)), whereas in T. antipodus, T. guamensis and T. orilloi the plate is octagonal in shape (Figure 11(b-d)); however, the genitoventral plate of $T$. palosapis appears to be weakly octagonal with three anterior and two lateral sides of an octogon weakly developed.

Besides the well-developed genitoventral plate shared by these species, T. palosapis, T. antipodus, T. guamensis and T. orilloi were all described from the Asia-Pacific region, indicating a biogeographic pattern. T. palosapis was described from specimens collected from native tree species in the Philippines, A. thurifera and S. squamata (Dipterocarpaceae), and has not been recorded since the original description. However, in contrast to what we know of other species of Tenuipalpus based on the literature, T. antipodus, T. guamensis and T. orilloi, have all been recorded from a wide range of host plants in several different countries, including New Zealand, Taiwan, Guam, the Cook Islands, the Philippines, Indonesia, Guiana, Trinidad and China, and have been intercepted at ports of entry in the United States and New Zealand.

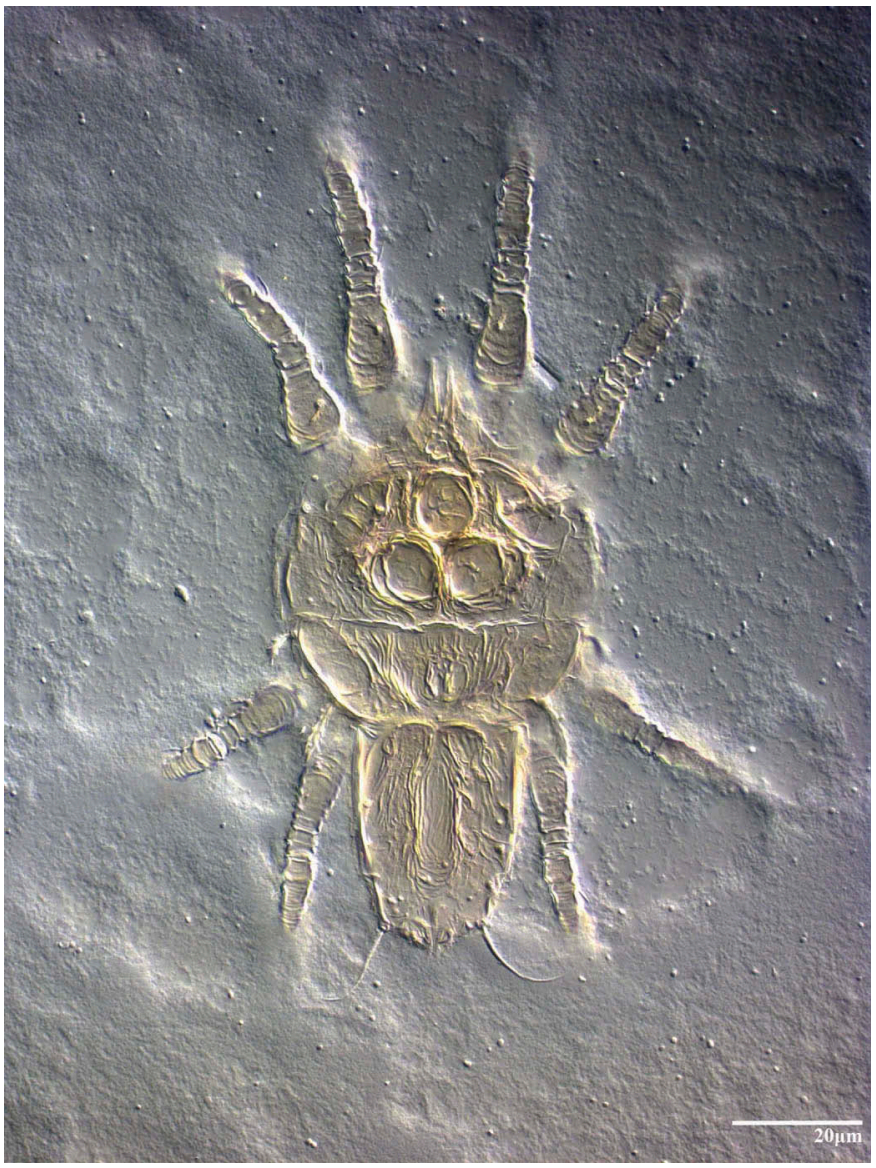

Figure 7. Differential interference contrast (DIC) image of Tenuipalpus palosapis Corpuz-Raros (Male): dorsal habitus.

Collyer (1964) lists the type material of $T$. antipodus as being collected from Melicytus ramiflorus J.R. Forst. and G. Forst. (Violaceae), from New Zealand, but states that the species is also commonly collected from other bush plants, including Coprosma spp. (Rubiaceae) and Nothopanax sp. (Araliaceae). This species was later recorded infesting tea Camellia sinensis (L.) Kuntze (Theaceae) and Beilschmiedia erythrophloia Hayata (Lauraceae) in Taiwan (Lo 1969, 1986; Tseng 1977), and Collyer (1973) herself later recorded T. antipodus on Hedycarya arborea J.R. Forst. and G. Forst. (Monimiaceae), Dysoxylum spectabile (G. Forst.) Hook.f. (Meliaceae), Beilschmiedia tawa (A.Cunn.) Kirk (Lauraceae) and Pseudowintera axillaris (J.R. Forst. and G. Forst.) Dandy (Winteraceae) in New Zealand. Collyer (1973) also noted that $T$. antipodus and $T$. orilloi are known to occur on a wide range of host plants.

Tenuipalpus guamensis was described from bird's nest fern, Asplenium nidus L. (Aspleniaceae), from Sumay, Guam, intercepted in quarantine by USA (Baker 1945; De Leon 1966). Later, Collyer (1973) recorded this mite species in flower "head-bands" from Tahiti intercepted in quarantine by New Zealand, from an unnamed fern frond (Polypodiaceae) woven into the bands. Gerson and Collyer (1984) recorded T. guamensis from ferns Dicranopteris linearis (Burm. f.) Underw. (Gleicheniaceae) and Nephrolepis hirsutula (G. Forst.) C. Presl (Nephrolepidaceae) from the Cook Islands. These authors also describe and illustrate damage caused by this species on $N$. hirsutula. The records from three different localities, Guam, Tahiti and the Cook Islands, indicate that $T$. guamensis is widespread in the Pacific region. All previous host records are species of ferns, but it could potentially also occur on additional host plant species throughout the region.

Rimando (1962) described T. orilloi from coconut, Cocos nucifera L. (Arecaceae) and Citrus sp. (Rutaceae), from the Philippines. 


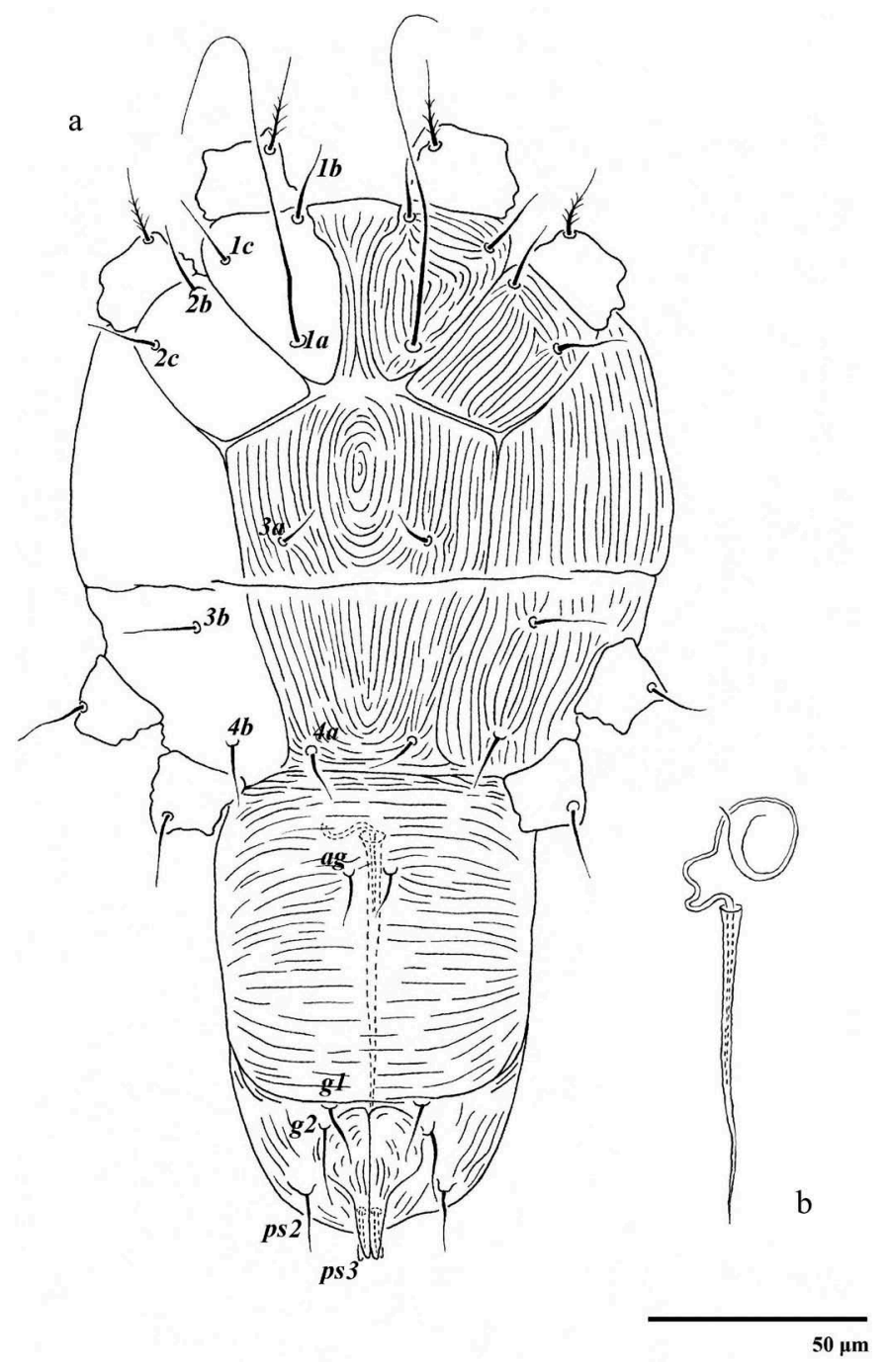

Figure 8. Tenuipalpus palosapis Corpuz-Raros (Male): a venter; b aedeagus.
The association with citrus indicated by Rimando (1962) is probably accidental because only one specimen was collected on this host. Manson (1963) described Tenuipalpus spathiphyllus based on specimens intercepted in quarantine on peace lily Spathiphyllum sp. (Araceae) from Indonesia at Washington D.C., USA. Two years later, De Leon (1965) collected T. orilloi on golden cane palm Chrysalidocarpus lutescens $\mathrm{H}$. Wendl. (sic) (currently Dypsis lutescens (H. Wendl.) Beentje and J. Dransf.) (Arecaceae) and on an unknown broad-leaved tree from Guiana. He synonymized $T$. spathiphyllus with $T$. orilloi and mentioned that this species was less restricted in host preference than were most Tenuipalpus known in that time.

Later, De Leon (1967) reported an association between T. orilloi and the predatory mite groups Phytoseiidae and Camerobiidae in Trinidad. These associations were as follows, T. orilloi with: Typhlodromina conspiccua (Garman) (Phytoseiidae) on Hura crepitans L. (Euphorbiaceae); Amblyseius largoensis (Muma) (Phytoseiidae) on C. nucifera and Corypha umbraculifera L. (Arecaceae); and Neophyllobius fissus De Leon (Camerobiidae) on C. nucifera and Caryota urens L. (Arecaceae). De Leon (1967) also reported T. orilloi on Saraca indica L. (Fabaceae), Stylogyne lateriflora (Sw.) Mez (Primulaceae) and Citharexylum fruticosum L. (sic.) (currently C. spinosum L.), (Verbenaceae) in Trinidad.

Corpuz-Raros (1989) reported associations between Phytoseiidae and Bdellidae and T. orilloi in the Philippines. This association occurred as follows, T. orilloi with: Amblyseius cinctus Corpuz and Rimando (Phytoseiidae) on Citrus mitis Blanco, Citrus nobilis Lour. (Rutaceae) and Gmelina arborea Roxb. (Lamiaceae); A. largoensis on Chrysophyllum cainito L. (Sapotaceae); Proprioseiopsis lenis (Corpuz and Rimando) (Phytoseiidae) on C. nobilis; Paraphytoseius multidentalis Swirski and Schechter (Phytoseiidae) on Ch. cainito; Phytoseius glareosus Corpuz (Phytoseiidae) on Ch. cainito; Ph. rasilis Corpuz on G. arborea; Chanteius contiguus (Chant) (Phytoseiidae) on Bambusa vulgaris Schrad. (Poaceae), C. nobilis and Tagetes foetidissima Hort. ex DC. (Asteraceae); and Bdellodes harpax Atyeo (Bdellidae) on Bischofia javanica Blume (Phyllanthaceae) and Caryota cumingii Lodd. ex Mart.(Arecaceae).
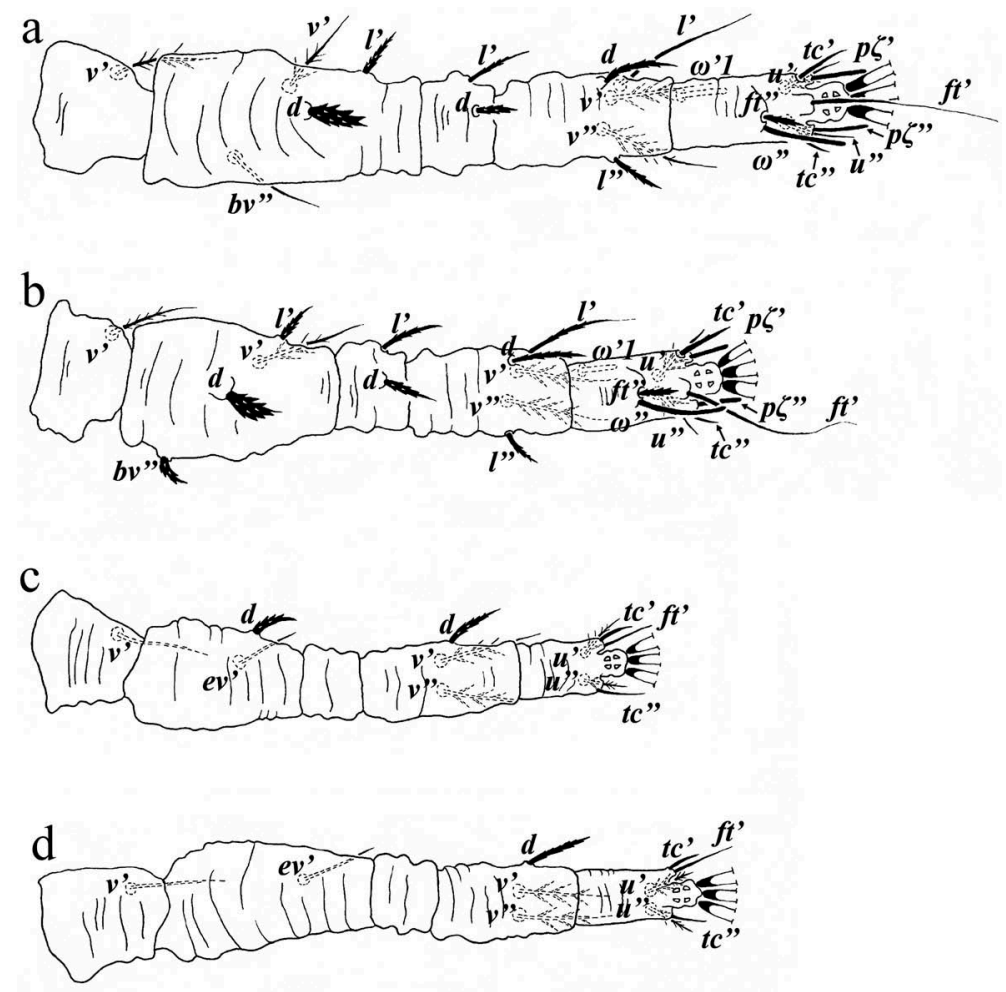

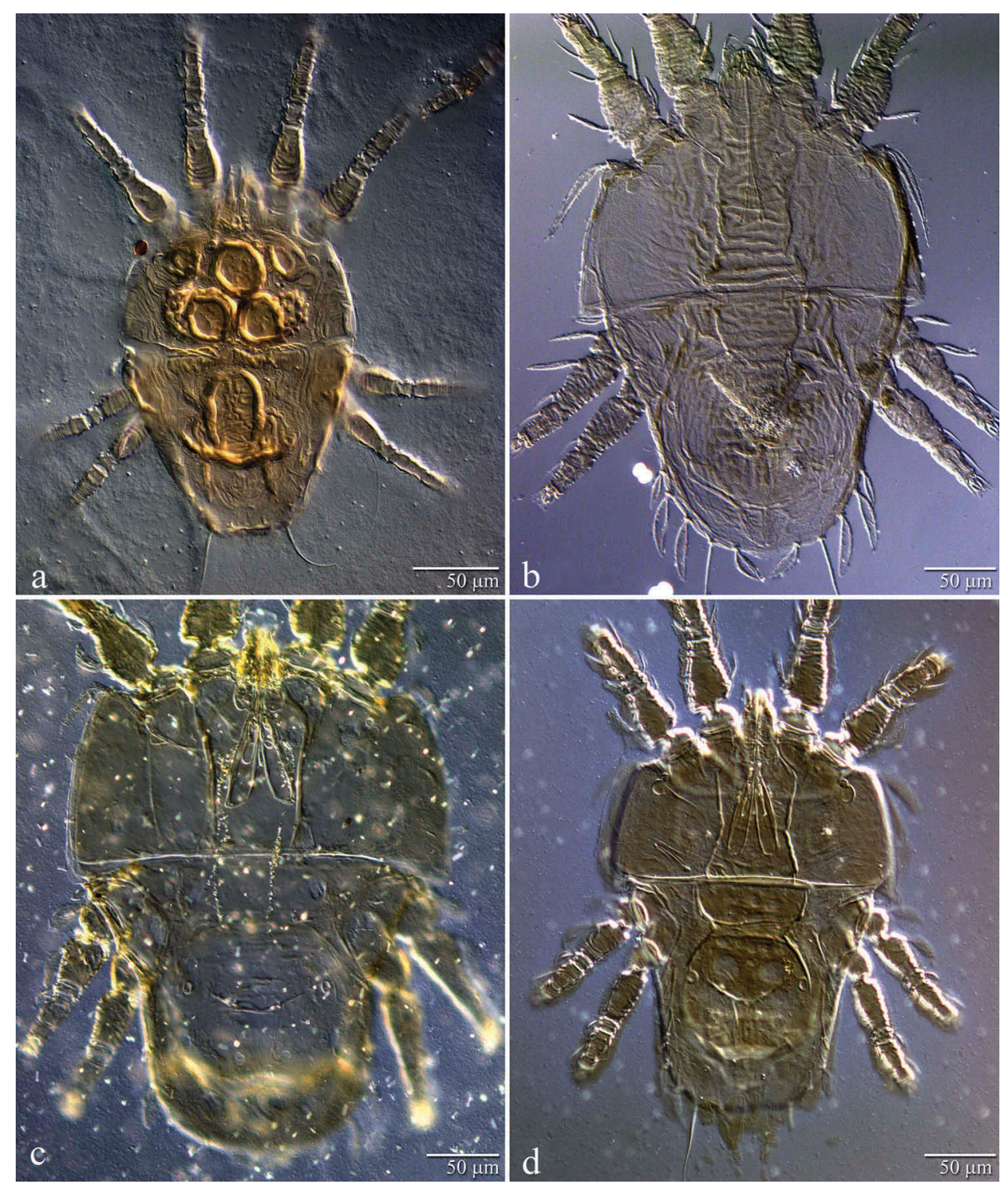

Figure 10. Female dorsal habitus: a Tenuipalpus palosapis Corpuz-Raros; b Tenuipalpus antipodus Collyer; c Tenuipalpus guamensis Baker; d Tenuipalpus orilloi Rimando.

Corpuz-Raros (1989) also reported T. orilloi for the first time on Acalypha hispida Burm.f. (Euphorbiaceae); Astronia cumingiana S. Vidal (Melastomataceae), Beaumontia pandacaqui (sic) (Tabernaemontana pandacaqui Lam., Apocynaceae), Casearia fuliginosa (Blanco) Blanco (Salicaceae), Citrus grandis (L.) Osbeck (sic) (syn. of Citrus maxima (Burm.) Merr), (Rutaceae), Coffea excelsa A. Chev. (sic) (syn. of Coffea liberica var. dewevrei (De Wild. and T. Durand) Lebrun, Rubiaceae), Cratoxylum celebicum Blume (Hypericaceae), Ficus septica Burm.f. (Moraceae), Leea philippinensis Merr. (Vitaceae), Livistona rotundifolia (Lam.) Mart. (sic) (syn. of Saribus rotundifolius (Lam.) Blume), (Arecaceae), Psychotria luzoniensis (Cham. and Schltdl.) Fern.-Vill. (Rubiaceae), Rubia sp. (Rubiaceae), Spathodea campanulata P. Beauv. (Bignoniaceae), Strombosia philippinensis S. Vidal (Strombosiaceae), Terminalia citrina Roxb. ex Fleming (Combretaceae) and Theobroma cacao L. (Malvaceae).

Recently, Xu and Fan (2010) provided a detailed redescription of $T$. orilloi female based on specimens collected on the palm Phoenix roebelenii O'Brien (Arecaceae) from China. These authors also mentioned the broad host range and potentially wide distribution of this species. To date, T. orilloi has been reported on 36 different host plants belonging to 22 families, from five different countries, the Philippines, Indonesia, Guiana, Trinidad and China. Based on reports and comments on the host associations of this mite species (De Leon 1965; Corpuz-Raros 1989; Xu and Fan 2010), T. orilloi appears strongly associated with two monocot plant families, the palm family Arecaceae and perhaps the lily family Araceae (monocotyledons), while other dicot plant families that have been recorded as host plants may need reevaluating, as neither substantial populations nor immatures were recorded on these hosts.

The wide range of host plants, including several economic palms and ornamentals, that are affected by the mite species $T$. antipodus, T. orilloi and T. guamensis, and the quarantine interception records from different countries, together indicate the importance of these three tenuipalpids as potential invasive species. The damage caused, life cycles, host associations and natural enemies of these species are in need of additional research.

\section{Key to species of Tenuipalpus with a well-developed genitoventral plate (based on females)}

1. Dorsal opisthosomal setae $c 1$ and $d 1$ absent; prodorsum completely sculptured; central region of prodorsum with three distinctive globose projections.

T. palosapis Corpuz-Raros

- Dorsal opisthosomal setae $c 1$ and $d 1$ present; prodorsum not as mentioned above

2. Dorsal opisthosomal setae $e 3$ half to three quarters the length to setae $f 2$ and $f 3$. T. antipodus Collyer 

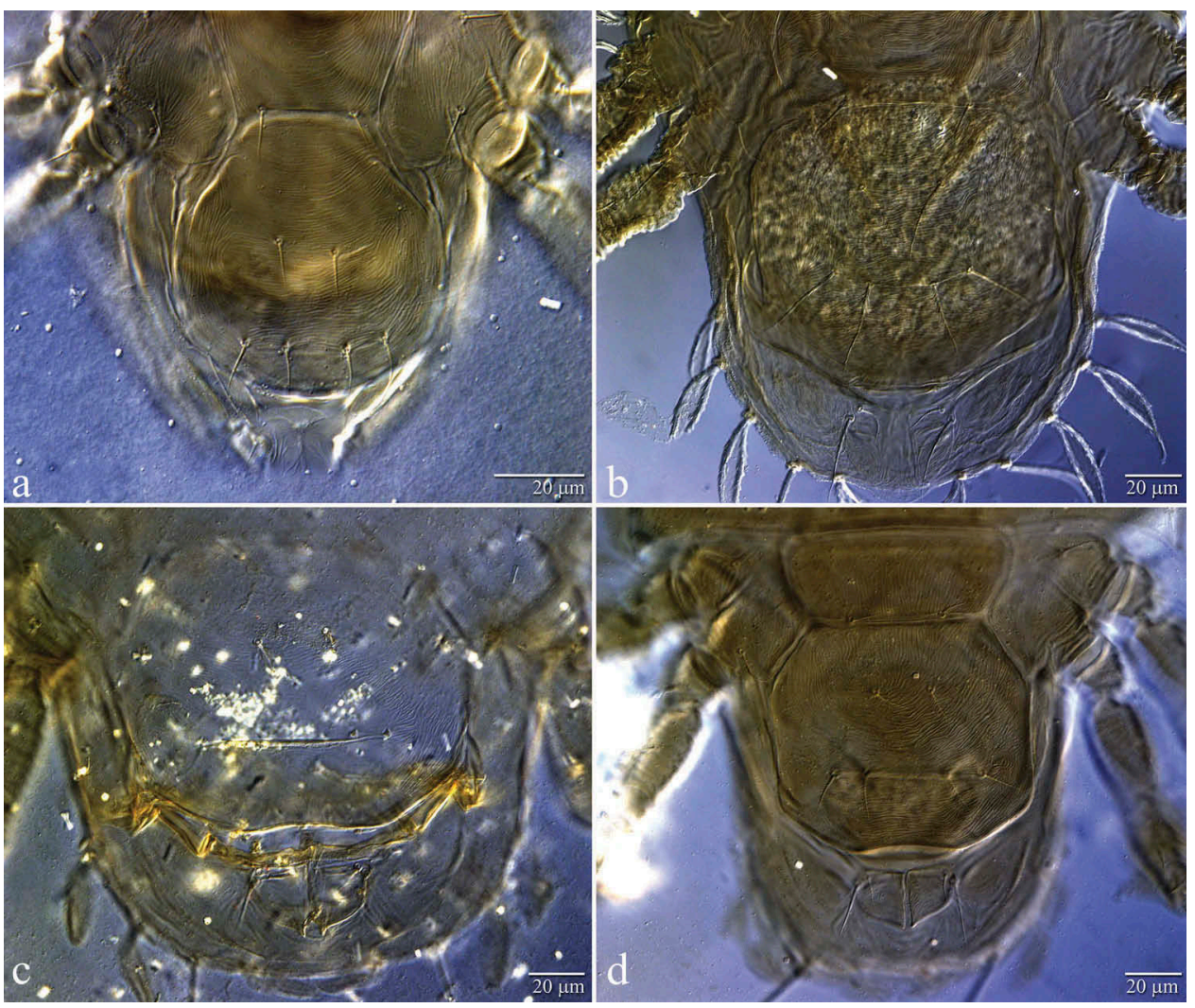

Figure 11. Posterior venter with detail of genitoventral and anal plates (female): a Tenuipalpus palosapis Corpuz-Raros; b Tenuipalpus antipodus Collyer; $\mathrm{c}$ Tenuipalpus guamensis Baker; d Tenuipalpus orilloi Rimando.

- Dorsal opisthosomal setae e3 minute, distinctly much smaller than setae $f 2$ and $f 3$. 3

3. Prodorsal setae $s c 2$ of similar length to $v 2$; dorsal opisthosomal setae $c 1, d 1$ and $e 1$ short (4-8 long). T. orilloi Rimando

- Prodorsal setae sc2 distinctly smaller than v2; dorsal opisthosomal setae $c 1, d 1$ and $e 1$ minute (3 long). T. guamensis Baker

\section{Acknowledgments}

We thank Dr. Gregory Evans (APHIS-USDA) for the revision and helpful suggestions on the manuscript. To Debra Creel and Andrew Ulsamer (SEL-USDA) for their help with references and technical support; to Chris Pooley (ECMU-USDA) for his help with the figures. To the Smithsonian Natural History Museum and National Agricultural Library (NAL-USDA), SEL-USDA for support and assistance with specimens and references. USDA is an equal opportunity provider and employer.

\section{Disclosure statement}

No potential conflict of interest was reported by the authors.

\section{Funding}

This work was supported by the "Fundação de Amparo à Pesquisa do Estado de São Paulo" (FAPESP) [Procs. 2016/01193-5 and 2017/ 00458-8], by fellowship to the first autor; the second author was funded by a research grant from the Australian Biological Resources Study, Department of Environment and Energy, Australian Government [grant RF214-23]; and by the "Conselho Nacional de Desenvolvimento Científico e Tecnológico" (CNPq) [Proc. 303435/2013-5] by a research grant to the fourth author.

\section{References}

Baker EW. 1945. Mites of the genus Tenuipalpus (Acarina: Trichadenidae). Proceedings of the Entomological Society of Washington. 47:33-38.

Baker EW, Tuttle DM. 1987. The false spider mites of Mexico (Tenuipalpidae: Acari). United States Department of Agriculture, Agricultural Research Service, Technical Bulletin. 1706:1-236.

Beard JJ, Otley J, Seeman OD. 2016. A review of Ultratenuipalpus (Trombidiformes: Tenuipalpidae) and related genera, with a new species from forest oak Allocasuarina torulosa (Aiton) (Casuarinaceae). International Journal of Acarology. 42:285-302.

Beard JJ, Seeman OD, Bauchan GR. 2014. Tenuipalpidae (Acari: Trombidiformes) from Casuarinaceae (Fagales). Zootaxa. 3778:1157.

Castro EB, Feres RJF, Ochoa R, Bauchan GR. 2016a. A new species of Tenuipalpus sensu stricto (Acari: Tenuipalpidae) from Brazil, with ontogeny and a key to the known species. Zootaxa. 4088:355-378.

Castro EB, Kane EC, Feres RJF, Ochoa R, Bauchan GR. 2016b. Definition of Tenuipalpus sensu stricto (Acari, Tenuipalpidae), with redescription of Tenuipalpus caudatus (Dugès) and description of a new species from Costa Rica. International Journal of Acarology. 42:106-126.

Castro EB, Ochoa R, Feres RJF, Beard JJ, Bauchan GR. 2015. Reinstatement of the genus Colopalpus Pritchard and Baker (1958) and re-description of Colopalpus matthyssei Pritchard and Baker (1958), the type species of the genus (Acari, Tenuipalpidae). International Journal of Acarology. 41:310-328.

Castro EB, Ramos FAM, Feres RJF, Ochoa R, Bauchan GR. 2017. Redescription of Tenuipalpus heveae Baker (Acari: Tenuipalpidae) and description of a new species from rubber trees in Brazil. Acarologia. 57:421-458.

Collyer E. 1964. New species of Tenuipalpus (Acarina: Tenuipalpidae) from New Zealand. Acarologia. 6:432-440.

Collyer E. 1973. New species of the genus Tenuipalpus (Acari: Tenuipalpidae) from New Zealand, with a key to the world fauna. New Zealand Journal of Science. 16:915-955. 
Corpuz-Raros LA. 1978. New Philippine Tetranychoidea (Acarina). Kalikasan, Philippines Journal of Biology. 7:211-230.

Corpuz-Raros LA. 1989. Hosts, geographic distribution and predatory mite associations of Philippines phytophagous mites (Acari). The Philippine Agriculturist. 72:303-322.

De Leon D. 1965. New Tenuipalpidae (false spider mites) from British Guiana with notes on four described species. Florida Entomologist. 48:65-75.

De Leon D. 1966. A new fern mite from Trinidad, West Indies (Acarina: tarsonemidae). Florida Entomologist. 49:127-129.

De Leon D. 1967. Some Mites of the Caribbean Area. Lawrence (Kansas): Allen Press, Inc. p. 1-46.

Gerson U, Collyer E. 1984. Two false spider mites (Acari: Tenuipalpidae) from Cook Islands and New Zealand ferns. New Zealand Journal of Zoology. 11:141-144.

Lindquist EE. 1985. External anatomy. In: Helle W, Sabelis MW, editors. Spider Mites: their biology, natural enemies and control. Vol. 1A. Amsterdam: Elsevier. p. 3-28.

Lo PKC. 1969. Tetranychoid mites infesting special crops in Taiwan. Bulletin Sun Yat-Sem Cultural Foundation. 4:43-82.

Lo PKC. 1986. Tetranychoid mites infesting tea in Taiwan. ChungSan Academic Cultural Affairs Serie. 1:275-286.

Manson DC. 1963. Seven new species of false spider mites (Tenuipalpidae: Acarina). Acarologia. 5:213-224.

Mesa NC, Ochoa R, Welbourn WC, Evans GA, de Moraes GJ. 2009. A catalog of the Tenuipalpidae (Acari) of the World with a key to genera. Zootaxa. 2098:1-185.
Meyer MKP. 1979. The Tenuipalpidae (Acari) of Africa with keys to the world fauna. Entomology Memoir, Department of Agriculture Republic South Africa, Pretoria. 50:1-133.

Meyer MKP. 1993. A revision of the genus Tenuipalpus Donnadieu (Acari: Tenuipalpidae) in the Afrotropical region. Entomology Memoir of the Department of Agriculture Republic South Africa. 88:1-84.

Rimando LC. 1962. The tetranychoid mites of the Philippines. University of Philippines, College Agricultural. Laguna, Technical Bulletin. 11:1-52.

Seeman OD, Beard JJ. 2011. A new species of Aegyptobia (Acari: Tenuipalpidae) from Myrtaceae in Australia. Systematic \& Applied Acarology. 16:73-89.

Tseng Y-H 1977. Systematic and distribution on phytophagous Mites in Taiwan, Part II. Tenuipalpidae. Bureau of Commodity Inspection and Quarantine, Ministry of Economic Affairs, Tainan Branch, 80pp.

Welbourn WC, Beard JJ, Bauchan GR, Ochoa R. 2017. Description of a new species of Tenuipalpus (Acari: Trombidiformes) from succulent plants in Florida, USA, and a redescription of $T$. crassulus Baker and Tuttle. International Journal of Acarology. 43:112-136.

Xu Y, Fan Q-H. 2010. Tenuipalpus orilloi Rimando, a new record to the Chinese fauna (Acari: Tenuipalpidae). Systematic \& Applied Acarology. 15:135-138.

Zhang Z-Q, Fan Q-H. 2004. Redescription of Dolichotetranychus ancistrus Baker \& Pritchard (Acari: Tenuipalpidae) from New Zealand. Systematic \& Applied Acarology. 9:111-131. 